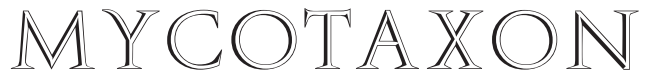

Volume 115, pp. 383-400

January-March 2011

DOI: $10.5248 / 115.383$

\title{
Rare or little known corticioid basidiomycetes from southern Belarus
}

\author{
Eugene Yurchenko ${ }^{1 *} \&$ Heikki Kotiranta ${ }^{2}$
}

${ }^{1}$ V.F. Kuprevich Institute of Experimental Botany, Akademichnaya str. 27, Minsk, BY-220072, Belarus

${ }^{2}$ Finnish Environment Institute, Natural Environment Centre, P.O. Box 140, Helsinki, FI-00251, Finland

CORRESPONDENCE TO *: ${ }^{* 1}$ eugene_yu@tut.by\& ${ }^{2} h e i k k i . k o t i r a n t a @ y m p a r i s t o . f i$

Abstract - Six non-poroid resupinate homobasidiomycete species, collected within the borders of Paleskaya Physiographic Province, or Polesia (Belarus), are described and illustrated: Crustodontia chrysocreas, Hyphoderma cryptocallimon, H. transiens, Oliveonia citrispora, Trechispora caucasica, T. minuta. According to the known distributional data, these taxa are rare or exceptionally rare in Belarus and other European countries; they are, except $H$. transiens, reported from Belarus for the first time. Distinctive characters and morphological differences from similar-looking species are discussed.

KeY wORDs - Basidiomycota, Corticiaceae, geography, morphology

\section{Introduction}

This paper continues a series on rare corticioid fungi from Belarus. Two previous publications were devoted to the species found in central (Yurchenko \& Kotiranta 2006) and northern (Yurchenko \& Kotiranta 2007) parts of the country. The species described here were found in southern Belarus and are rare or very rare in Belarus and most of the other European countries. The morphology of these species, except Crustodontia chrysocreas, is relatively little documented, and thus additional descriptions are needed.

\section{Materials \& methods}

The material was collected from Paleskaya Province, or province No.845 according to the European decimal physiographic division (see Klitsunova et al. 2002). In geographical literature this area is better known as Belarusian part of Polesia Lowland or Belarusian Palesse (FIg. 1). The corresponding author collected most of the specimens in 2006 and 2007; otherwise the collector's name is indicated. 

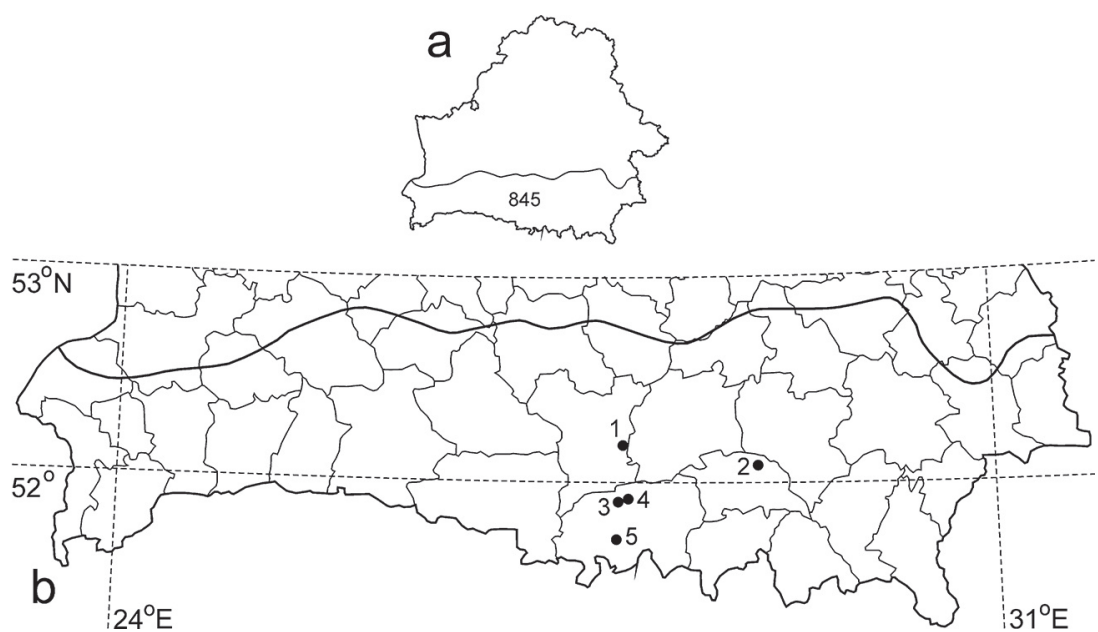

FIG. 1. Study area and collection sites: a, contour of the Republic of Belarus and Paleskaya Province (province No. 845, according to the European decimal physiographic division); b, collection sites, northern border of the Province and the borders of Belarus administrative districts (site numbers are the same as mentioned in SPECIMENS EXAMINED).

The macromorphology was described from dry samples. For micromorphological measurements and drawings the material was mounted in $3 \% \mathrm{KOH}$ water solution or in distilled water to observe crystals; Melzer's reagent (Mz's) was used to test amyloidity or dextrinoidity, and Cotton Blue (CB; $0.1 \%$ Cotton Blue in $60 \%$ lactic acid) to test for cyanophily. The studied samples are deposited in the Herbarium of V.F. Kuprevich Institute of Experimental Botany (MSK-F); duplicates are also deposited in the reference herbarium of Heikki Kotiranta (H.K.) and one in the University of Oslo Herbarium (O).

\section{Species descriptions}

Crustodontia chrysocreas (Berk. \& M.A. Curtis) Hjortstam \& Ryvarden

FIG. 2

BAsidioma totally effused, closely adnate, about $10 \times 5 \mathrm{~cm}, 50-100 \mu \mathrm{m}$ thick in dry state, ceraceous or subcartilaginous, somewhat fissured in dry state; hymenophore greyish ochraceous with orange tint, under the lens slightly pruinose, with the naked eye like grayish bloom, smooth or with minute, quite scattered, blunt warts. MARGIN concolorous, thinning out. SubICULUm rather thin and subhymenium thick; subhymenium with pigmented resinous inclusions. HyPHAL SYSTEM monomitic, hyphae clamped at all septa. Subicular hyphae moderately branched, more or less sinuous, even or with swellings, 2.2-4.1 $\mu \mathrm{m}$ wide, hyaline, thin- to slightly thick-walled, smooth. Subhymenial hyphae densely branched, short-celled, densely packed and forming a pseudoparenchymatic tissue, 2-3 $\mu \mathrm{m}$ wide, with swellings up to $4 \mu \mathrm{m}$ wide, 
hyaline, thin- or slightly thick-walled, smooth. Hymenium consisting of densely palisade-arranged cells, with brownish resinous excretions in between. Cystidioles (leptocystidia) fusoid, blunt, about $20 \mu \mathrm{m}$ long, 2.3-4.3 $\mu$ m wide, projecting 6-8 $\mu \mathrm{m}$ above the hymenium, hyaline, thin-walled, naked or apically with capitate, pale brownish or yellow encrustations, 2.2-6.7 $\mu \mathrm{m}$ in diam. BASIDIA cylindrical or narrowly clavate, $16-21 \times 3.8-4.2 \mu \mathrm{m}$, hyaline, thinwalled, with 4 sterigmata $6-6.5 \times 0.8 \mu \mathrm{m}$. BAsidiospores narrowly ellipsoid, (3.7-)4.2-4.7(-5.5) $\times(2-) 2.2-2.3 \mu \mathrm{m}$, mostly slightly thick-walled, hyaline or subhyaline, with very small apiculus, Mz's-negative, acyanophilous.

SPECIMEN EXAMINED-BELARUS. Homel' voblast': Lel'chytsy district, in vicinity of Baravoe village (site 5), on decorticated fallen wood of Quercus robur L. in Quercus forest of Vaccinium myrtillus type, coll. E.P. Komarova 22 VIII 1963 (MSK 10574; H.K.; O).

Crustodontia chrysocreas is distinguished by its slightly warted hymenial surface, usually ochraceous hymenium with orange and brownish hues, short-celled, and tightly packed hyphae in textura intricata, which gives the basidioma a cartilaginous consistency (Lombard et al. 1975 as 'Phlebia chrysocrea (Berk. \& M.A. Curtis) Burds., Domański 1991 as 'Ph. chrysocreas'). Our specimen fits C. chrysocreas in colour, hymenial configuration, basidioma texture, leptocystidia, basidia, and spore morphology. However, we did not observe microbinding hyphae or the waxy, yellow substance described by Lombard et al. (1975) in the substratum under the basidioma. Moreover, no parts of the fungus turned red in $3 \% \mathrm{KOH}$, which is characteristic for American (Lombard et al. 1975), Hawaiian (Gilbertson \& Adaskaveg 1993), and Japanese (Maekawa 1993) material. Microbinding hyphae were not observed in Asian material (Wu 1990 as 'Amethicium chrysocreas (Berk. \& M.A. Curtis) Sheng H. Wu', Maekawa 1993). Abundant yellowish (but not orange brown, as in the American samples) granular material was found in subhymenium and especially hymenium, but absent in subiculum. The colour differences and the absence of $\mathrm{KOH}$ reaction is probably due to the long-time storage of the specimen in herbarium. Remarkably, in his original description of Corticium chrysocreas Berk. \& M.A. Curtis, Berkeley stated, "subiculum bright yellow" (Berkeley 1873: 178), but Maekawa (1993) described the fungus as pale yellow in section. Our sample has smaller (although similarly shaped) cystidia compared with those described by Lombard et al. (1975) and Maekawa (1993). The material described from Hawaii (Gilbertson \& Adaskaveg 1993) had oblong to cylindrical spores and remarkable hyphal elements with vesicular apices up to $22 \mu \mathrm{m}$ wide, which are absent in our sample.

The species is new for Belarus and the record is the northernmost $\left(51.7^{\circ} \mathrm{N}\right)$ known in the world. It has a pantropical distribution and is exceptionally rare in Europe, earlier collected in France (Bourdot \& Galzin 1928), Poland, and 

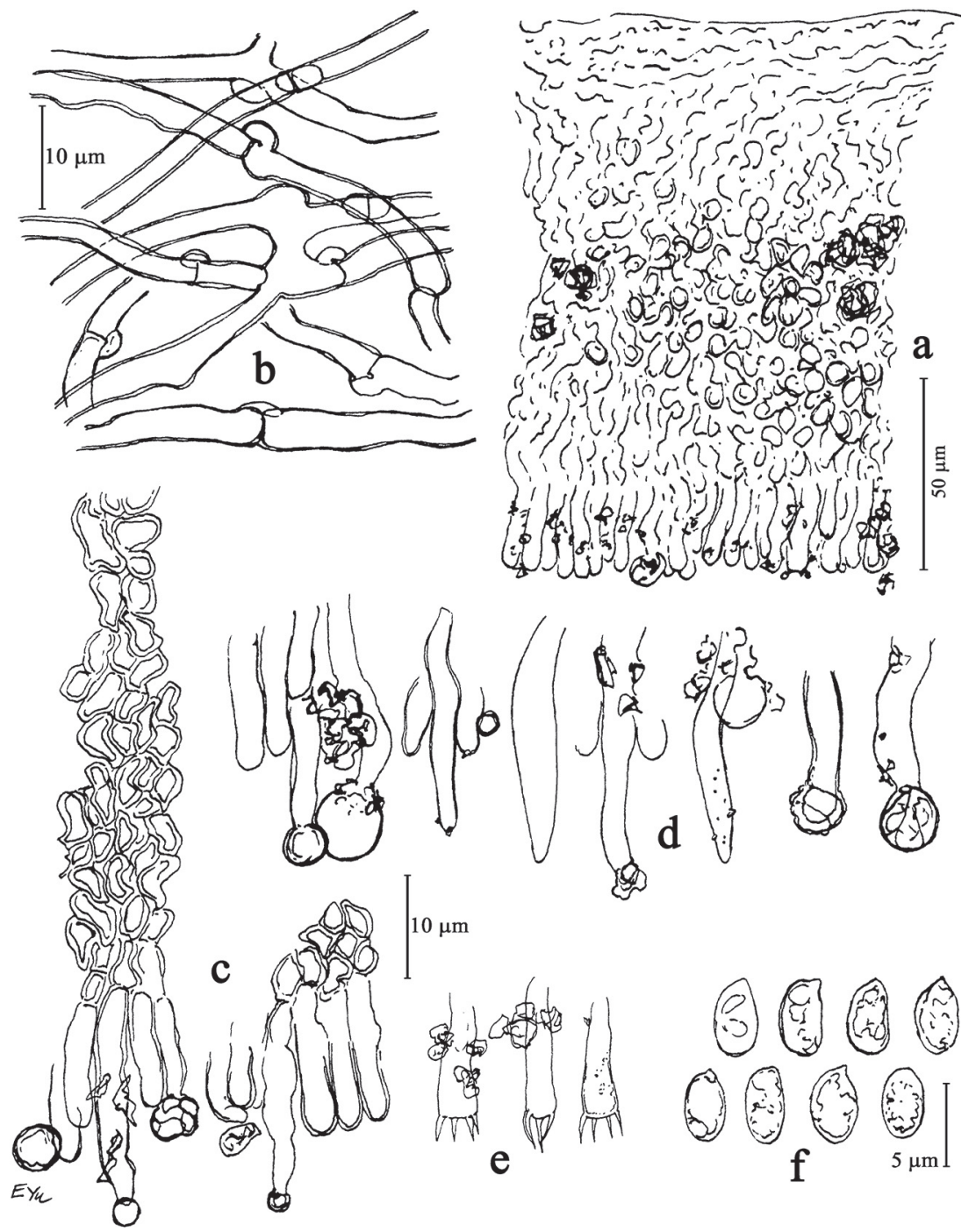

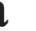
. 
(Hjortstam et al. 1993, Roberts 2000), Sri Lanka (Lombard et al. 1975), southern and southeast China (Dai et al. 2004, Dai 2010), Taiwan (Lin \& Chen 1990, Wu 1990), Japan (Maekawa 1993 - 8 localities; Kubayashi \& Maekawa 2001), Hawaii (Gilbertson \& Adaskaveg 1993), Brunei (Hjortstam et al. 1998), western Australia (Hjortstam et al. 2009), New Zealand (Pennycook \& Galloway 2004). We suppose, in accordance with Hjortstam et al. (2009), that the material from different isolated landmasses is heterogeneous, comprising several species, which is reflected in differences in descriptions.

\section{Hyphoderma cryptocallimon B. de Vries}

BAsidioma effused, closely adnate, subceraceous, several $\mathrm{cm}$ long, 0.1-0.2 $\mathrm{mm}$ thick, smooth and continuous to porulose, especially towards the margin, cream- or pale coloured. MARgin diffuse. Hyphal system monomitic. Subicular hyphae clamped, moderately branched, 2-3.7 $\mu \mathrm{m}$ wide, hyaline, thinwalled. Cystidia scattered, projecting up to $65-100 \mu \mathrm{m}$ above the hymenium, cylindrical or with some dilatations towards the base and/or to the apex, apically occasionally subcapitate or with a small resinous cap, non-septate or seldom with $1-3$ adventitious septa, $70-90(-125) \times 5.5-9.2 \mu \mathrm{m}$, hyaline, apically thinwalled, at the base slightly or distinctly thick-walled (to $1 \mu \mathrm{m}$ ). HypHidia numerous in some hymenial areas, cylindrical, hyaline, thin-walled, straight to sinuous, $1.5-2.3 \mu \mathrm{m}$ wide, projecting up to 5-15 $\mu \mathrm{m}$. BAsIdIOLES often rich in oil-drops. BAsIDIA subcylindrical or narrowly clavate, hyaline, thin-walled, rich of oily inclusions, $(30-) 45-50 \times 7-10.3 \mu \mathrm{m}$, with (2) 4 sterigmata $6.5-9 \times$ 1.3-1.7 $\mu \mathrm{m}$, some sterigmata basally with an oily inclusion, with attenuated to hair-like tip when mature. BAsIDIOSPOREs narrowly ellipsoid to oblong, sometimes narrowing to the base, $(8.5-) 9.5-11(-13.5) \times(4.5-) 5-5.5(-6.7) \mu \mathrm{m}$, hyaline, often with a large, strongly refractive oil drop, thin-walled, smooth, with rather narrow, distinct apiculus, inamyloid, acyanophilous.

SPECIMEN EXAMINED-BELARUS. Homel' voblast': Lel'chytsy district, in vicinity of Simanichy village (site 3), on fallen decorticated branch of Pinus sylvestris L. in Pinus forest of Pleurozium type, coll. 9.XI.2007 (MSK 6904; H.K.). The fungus is mixed with Tubulicrinis subulatus (Bourdot \& Galzin) Donk basidioma, and grew over it.

Eriksson \& Ryvarden (1975: 543) first diagnosed this taxon under the name Hyphoderma sp. de Vries 488, based on a single sample from northwest Germany. Nakasone \& Gilbertson (1982: 603-605) described a new species in the genus Crustoderma, C. opuntiae Nakasone \& Gilb., from Arizona, with the notation that it is morphologically similar to Hyphoderma sp. de Vries 488. However, we see several differences between the C. opuntiae and H. cryptocallimon diagnoses that do not support their synonymy: C. opuntiae has floccose subiculum with moderately thick-walled hyphae, somewhat flexuose cystidia, narrower basidia (6-7 $\mu \mathrm{m})$ of narrowly clavate shape, narrower spores (4-5 um wide), and 

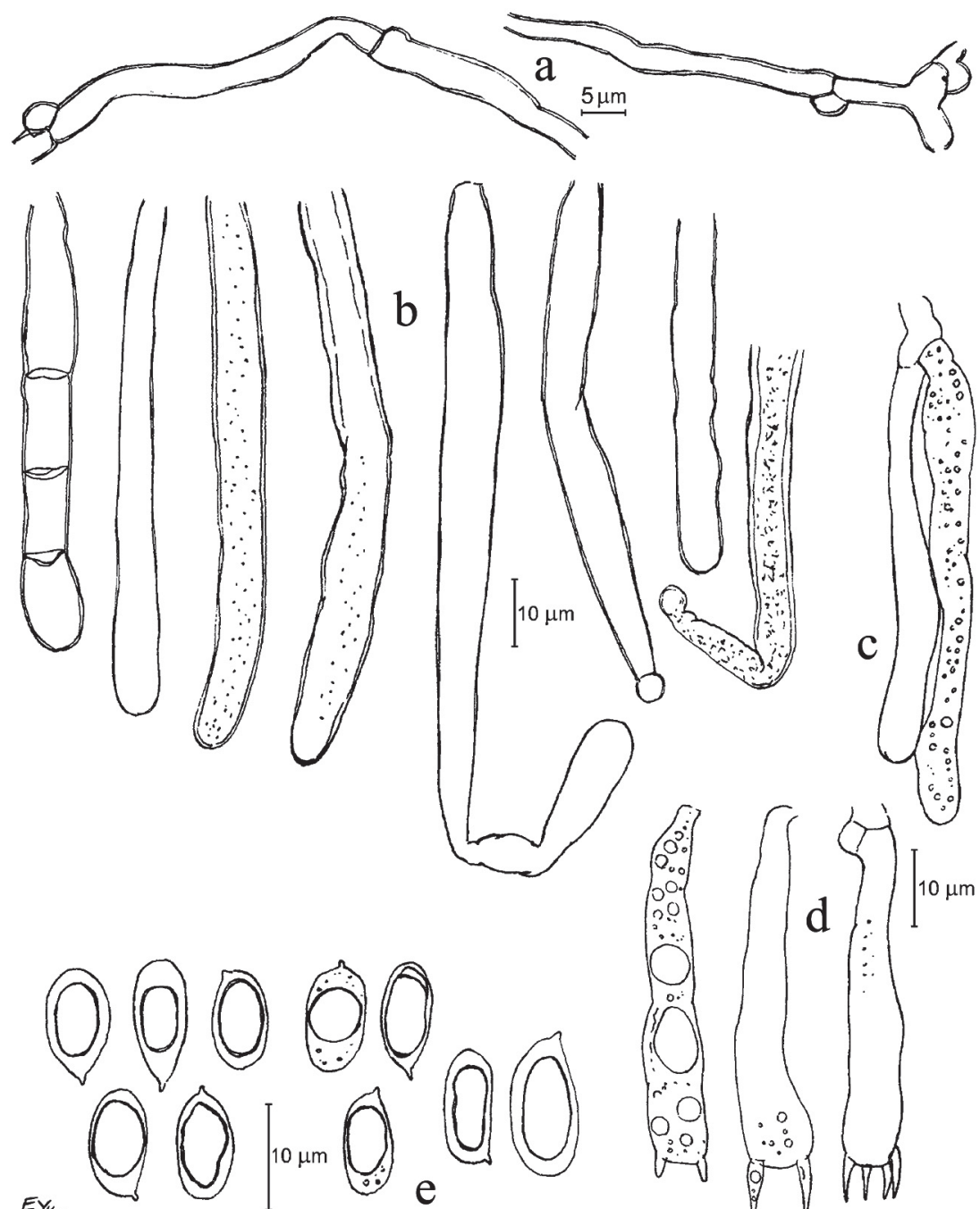

EY⿸厂

e
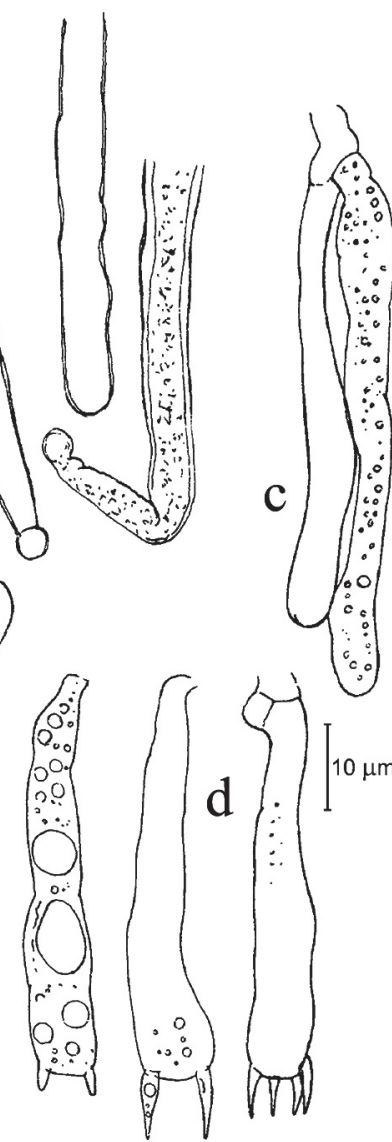

FIG. 3. Hyphoderma cryptocallimon (MSK 6904): a, subicular hyphae; b, cystidia; c, basidioles; d, basidia; e, basidiospores.

negative oxidase test, indicating a brown rot activity, whereas the members of the genus Hyphoderma are white rot fungi.

Hyphoderma cryptocallimon is morphologically close to H. obtusiforme J. Erikss. \& Å. Strid, differing from it by shorter basidiospores, much longer and projecting cystidia that are often distally slightly clavate and basally with thickened or thick walls and sometimes with adventitious septa, and somewhat 
larger and slightly more sinuous basidia $(25-70 \times 7-10 \mu \mathrm{m})$, usually with many guttules (Eriksson \& Ryvarden 1975, de Vries 1987). Cystidia in H. obtusiforme are $50-80 \mu \mathrm{m}$ long, thin-walled and not subclavate; besides, they often have dense protoplasm in the distal part. The spore size in H. cryptocallimon is noted as 7-12 $\times$ 4.5-7 um, whereas spores are 10-14 × 5-7 $\mu \mathrm{m}$ in H. obtusiforme (Eriksson \& Ryvarden 1975, de Vries 1987). There is also a presumed ecological distinction: H. cryptocallimon prefers habitats on poorer sandy soils, which is seen at least from the finds described by de Vries and from our finding. Some spores in our material were longer than $12 \mu \mathrm{m}$, thus approaching the spore size of H. obtusiforme. Moreover, our sample has many cylindrical cystidia, only some of which expanded slightly toward the apex; some cystidia are subcapitate, uncommon for H. cryptocallimon.

The species is new for Belarus and known from a single locality. H. cryptocallimon was described on Juniperus communis from northwest Germany and reported also from southern Sweden and the Netherlands (de Vries 1987), Italy on Juniperus and Pinus (Bernicchia 2000, Bernicchia et al. 2007a), Zakarpats'ka oblast in Ukraine (Küffer et al. 2004), Britain including Northern Ireland (Kirk \& Cooper 2009), and Belgium and Spain (Bernicchia \& Gorjón 2010).

Hyphoderma transiens (Bres.) Parmasto

FIG. 4

BASIDIOMATA totally effused, more or less closely adnate, $5 \mathrm{~cm}$ or more in extent, 50-130 $\mu \mathrm{m}$ thick between the teeth, subceraceous, cream-coloured. HYMENOPHORE odontioid, at basidioma periphery partly smooth or minutely porulose; teeth tuberculate-flattened at the periphery of the basidioma, in the center conical or cylindrical, brownish or dark ochraceous, glossy, fragile, up to $0.4 \mathrm{~mm}$ long and $0.2 \mathrm{~mm}$ wide, simple or slightly branched, obtuse or acute, smooth or apically short-setaceous; with age or when dry basidioma minutely cracked. MARGIN farinaceous, diffuse, in some areas almost mouldlike (short-fibrillose), whitish or cream-coloured, 0.3-0.7 mm wide. HyPHAL SYSTEM monomitic, hyphae clamped at all septa. Subicular hyphae moderately branched, more or less loosely interwoven, 2-3.7 $\mu \mathrm{m}$ wide, hyaline, thin- to slightly thick-walled, smooth or sparsely encrusted (in $\mathrm{KOH}$ ). Tooth trama with abundant yellowish, coarse crystalline material (in water); apical hyphae of the teeth often forming clusters, individual hyphae 1.3-3.5 $\mu \mathrm{m}$ wide. Subhymenial hyphae moderately branched, more or less vertically arranged, 2-2.5 $\mu \mathrm{m}$ wide, hyaline, thin-walled, richly covered with aggregations of yellowish coarse crystalline material, not dissolved in KOH. Cystidia rare or scattered, more or less embedded, subcylindrical, 40-95 $\times 7-9(-10) \mu \mathrm{m}$, subhyaline, thin-walled, in $\mathrm{KOH}$ smooth. BAsIDIA irregularly clavate, 25-30 $(-38) \times 5.7-6.7 \mu \mathrm{m}$, hyaline, thin-walled, smooth or basally encrusted, with $2-4$ sterigmata, initially stout and obtuse, when mature conical or subulate, 6.5-9.5 


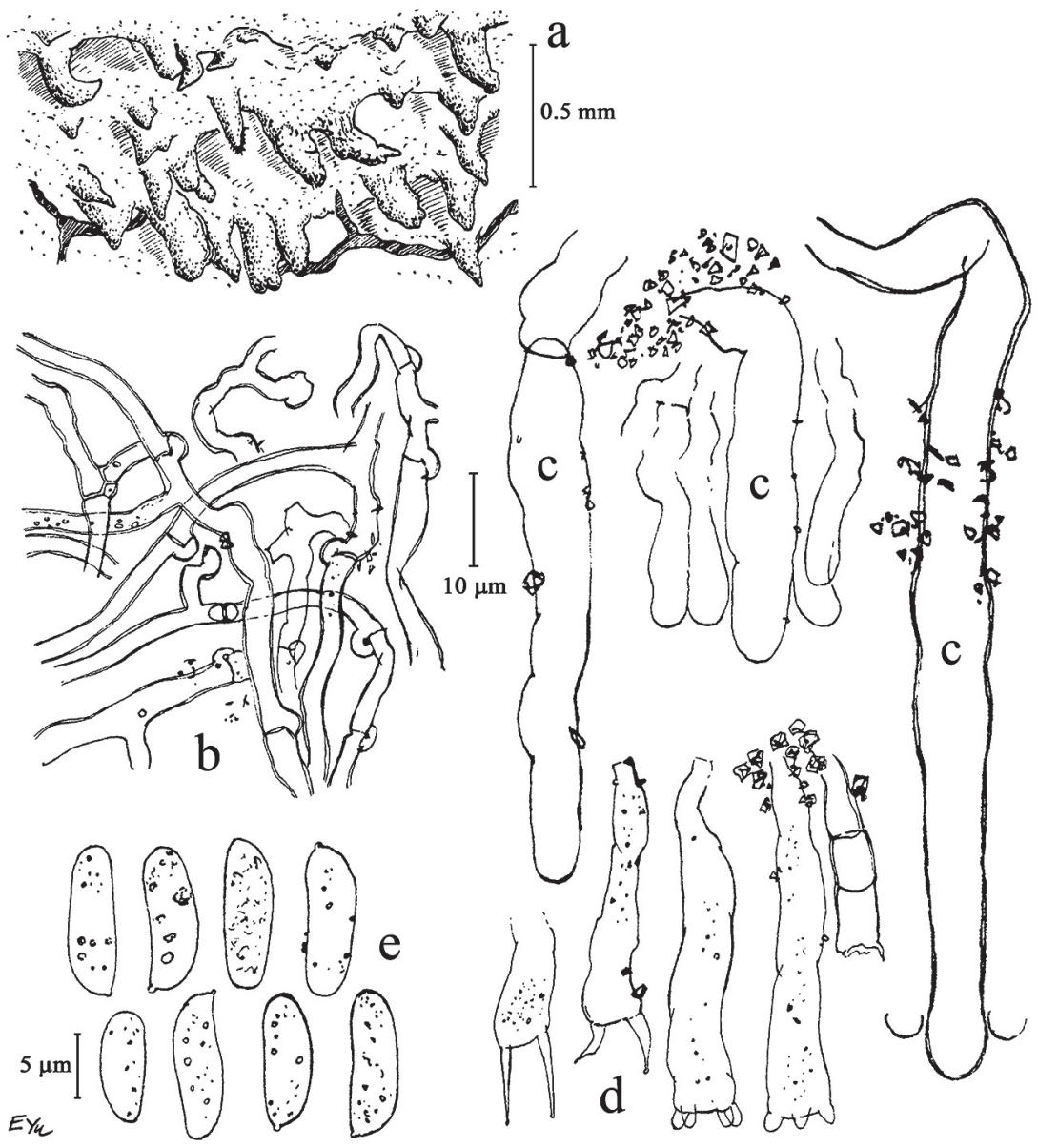

FIG. 4. Hyphoderma transiens (MSK 3965): a, view of odontioid hymenophore; b, subicular hyphae; c, cystidia; d, basidia; e, basidiospores.

$\times 1.5-1.8 \mu \mathrm{m}$. BASIDIOSPORES cylindrical, adaxially straight or slightly concave, occasionally gently sigmoid, $8.5-12 \times 2.7-4.1 \mu \mathrm{m}$, thin-walled, colourless, with small dispersed oil drops, with short and blunt, sometimes not pronounced apiculus, Mz's-negative, acyanophilous.

Specimens EXAMINED-BELARUS. Homel' voblast': Zhytkavichy district, in the vicinity of Naida village (site 1), on fallen corticated branch of Corylus avellana L. and unidentified deciduous tree in Alnus glutinosa forest of Urtica type, coll. A.I. Golovko 21.VIII.1967 (MSK 10505a, 10505b); Lel'chytsy district, in the vicinity of Baravoe village (site 5), on fallen decorticated wood of Populus tremula L. in Alnus glutinosa forest of Sphagnum type, coll. E.P. Komarova 17.VIII.1963 (MSK 3965). 
Distinctive characters of $H$. transiens are the odontioid hymenophore, which smoothens towards the basidioma periphery, crystal-rich aculeal trama, the presence of scattered, almost immersed subcylindrical cystidia (Maekawa 1994), and relatively narrow basidiospores. The hymenophore colour is usually pale ochraceous and varies little even between samples from different continents (Hjortstam \& Ramos Bononi 1987, Maekawa 1994). Other authors (Nikolajeva 1961 as 'Odontia transiens Bres.', Hjortstam \& Ramos Bononi 1987, Maekawa 1993: 12 as 'H. longosporum (H. Furuk.) N. Maek.', 1994: 65) noted longer basidiospores ( $\leq 13-15 \mu \mathrm{m})$. Nikolajeva (1961) described also cylindrical, spindle-shaped or slightly capitate apically encrusted (rough) cystidia, which were not observed by us. The same author described the hymenophore as warted with warts having penicillate apices, whereas our material is irregularly warted to irregularly short-aculeate, with barely pronounced or absent penicillate projections at aculei apices. A morphologically close species is H. roseocremeum (Bres.) Donk, but it differs by a smooth hymenophore.

Hyphoderma transiens was published for the first time from Belarus from the northwestern part of the country (Yurchenko 2008). Two other known sites are in the southern part, but the species has not been recollected there since 1967. The species is common in the Mediterranean and frequent on Quercus in Italy (Bernicchia et al. 2007b, 2008) and has been reported from many other warm regions: southern Brazil (Hjortstam \& Ramos Bononi 1987), Azores (Telleria et al. 2009a,b - common), Madeira (Telleria et al. 2008), Krasnodar krai of Russia, Georgia, Azerbaijan, northeast Turkey, northern Iran (Ghobad-Nejhad et al. 2009), north-central China (Dai et al. 2004, Dai 2010), Japan (Maekawa 1994). In the more northern areas there are records from the Carpathians and the Forest Steppe Zone of Ukraine (Nikolajeva 1961, Zerova et al. 1972 - under the name 'Odontia transiensis'), and Middle Volga Region in Russia (Malysheva \& Malysheva 2008). Bernicchia \& Gorjón (2010) cite the northernmost localities as Sweden and Estonia.

Oliveonia citrispora (Hauerslev) P. Roberts

FIG. 5

BAsidioma totally effused, 1-7 mm long, ca $30 \mu \mathrm{m}$ thick, hypochnoid, comparatively loosely attached to the substratum, not continuous, porulosereticulate, greyish with yellowish or brownish tint. MARGIN rather abrupt or indistinct. Subiculum poorly developed; subicular hyphae moderately branched, with small clamps or rarely with simple septa, (1.3-)1.6-2(-2.8) $\mu \mathrm{m}$ wide (some segments inflated to $4 \mu \mathrm{m}$ ), thin-walled, smooth, hyaline or with pale yellowish refractive contents. Subbasidial hyphae moderately branched, 1.8-2(-3) $\mu \mathrm{m}$ wide, thin-walled, hyaline or with yellowish contents, with clamped septa. Crstidia none, but broadly fusoid cystidioles scattered, $12-17.5 \times 3.2-4.7 \mu \mathrm{m}$, yellowish. BASIDIOLEs broadly clavate, narrowly ovoid 


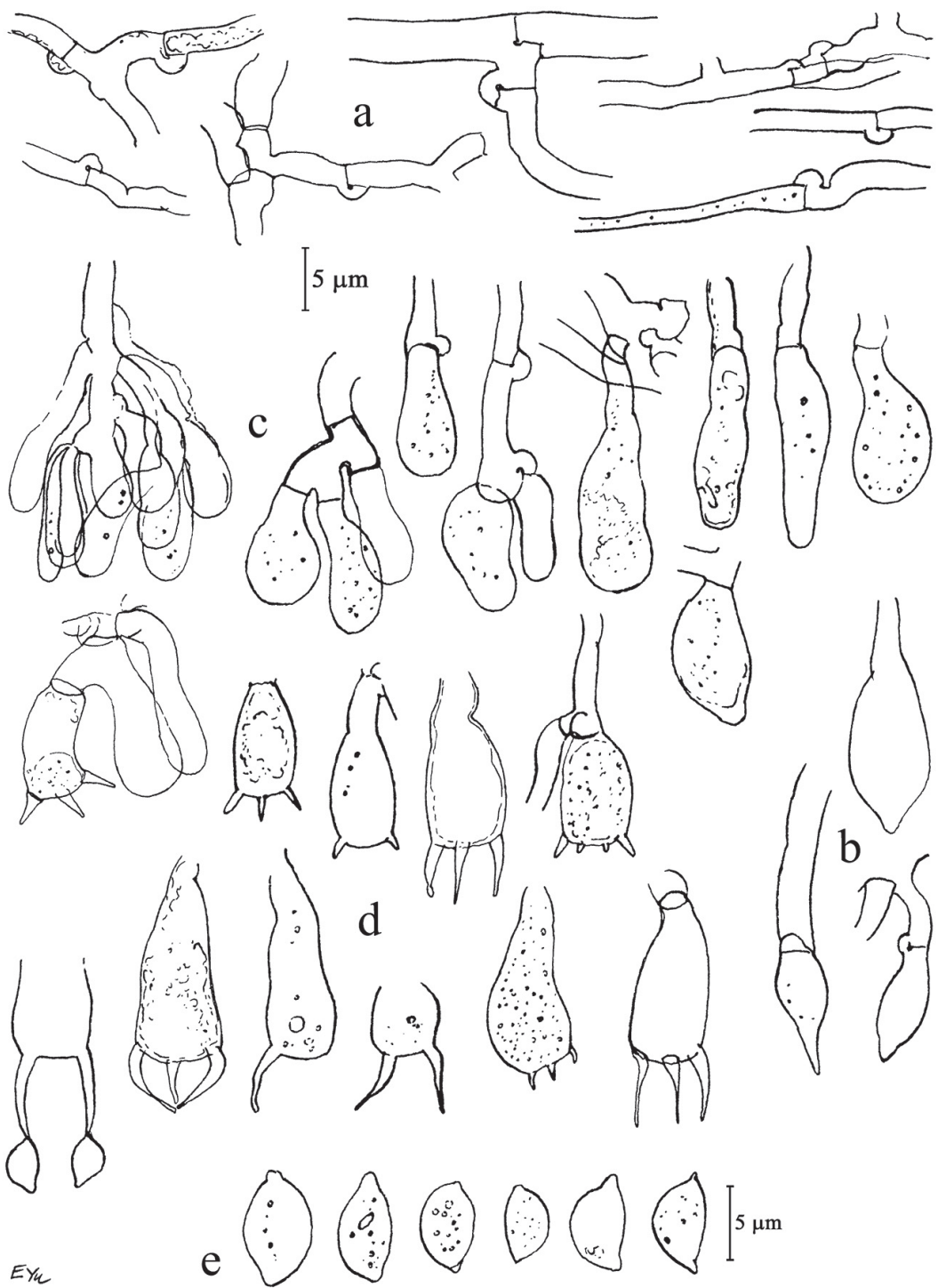

FIG. 5. Oliveonia citrispora (MSK 6895): a, subicular hyphae; b, broadly fusoid cystidioles; c, basidioles and basidia; $\mathbf{d}$, basidiospores.

or subcylindrical, $11-25 \times 5.7-7.5(-8.5) \mu \mathrm{m}$, with subhyaline to brownish yellow, minutely granular or refractive contents. BAsidia ovoid to broadly clavate, basally clamped (but the clamp not always seen), 10-16.5 × 4.5-7.7 $\mu \mathrm{m}$, hyaline or pale yellowish, thin-walled (wall thinner basally), with 1-4 
sterigmata, 2.2-6.5 $\times 0.8-1.1 \mu \mathrm{m}$. BASIDIOSPORES wide-navicular - citriform, narrowing towards both ends, (4.3-)6-8.2 × 2.9-4.3 $\mu \mathrm{m}$, thin-walled, smooth, hyaline to yellowish, with short blunt apiculus, Mz's-negative, acyanophilous.

Specimens exAmINED-BELARUS. Homel' voblast': Lel'chytsy district, Prypyatski National Park, in the vicinity of Simanitskaya Rudnya village (site 4), on decorticated wood of strongly decayed Picea abies (L.) H. Karst. stump in Betula-Picea forest of Vaccinium myrtillus type, coll. 9.XI.2007 (MSK 6895; H.K.); the same locality, on decaying Picea abies bark in Picea forest of swampy moss type, coll. 21.V.2010 (MSK 7291).

Oliveonia citrispora is distinguished from other members of the genus by biapiculate basidiospores. Our material deviates somewhat compared with other descriptions of the species. According to Roberts (1999), O. citrispora has narrower $(1.5-2 \mu \mathrm{m})$ hyphae, subglobose, cuboid or ellipsoid basidia that are shorter $(7.5-11 \mu \mathrm{m})$ and often pleural, larger sterigmata $(4-10 \times 1-1.5$ $\mu \mathrm{m})$ and larger basidiospores $(6-10 \times 3.5-8 \mu \mathrm{m})$ with pronounced apiculi. However, such small differences are common in Rhizoctonia-forming fungi. Basidiospores in our material are notably narrow, even when compared with the data by Roberts (1999: Tab. 30) for a sample with the narrowest spores (up to $6 \mathrm{um}$ ). Our samples have a dirty yellowish pigmentation in hymenial elements and hyphae, giving a yellowish or brownish tinge to the hymenial surface, whereas basidiomata are greyish-white according to other descriptions (Hauerslev \& Roberts 1997 as 'Sebacinella citrispora Hauerslev', Roberts 1999). Spore repetition is often found in this taxon (Hauerslev \& Roberts 1997) but was not detected in the specimens examined here.

The species is new for Belarus and known from a single locality. It is probably rare over its entire small range: so far it is known from the Netherlands, Denmark (Roberts 1999), southern Britain (Kirk \& Cooper 2009 - 7 records), and Sweden (Bernicchia \& Gorjón 2010).

\section{Trechispora caucasica (Parmasto) Liberta}

FIG. 6.

BAsidiomata totally effused, ca 5-15 mm long, very thin, closely adnate but not firmly attached to the substratum, pure white, arachnoid-reticulate, with scattered loose granules, $0.2-1 \mathrm{~mm}$ in diam., containing conidia or hyphae with abundant coarse crystalline material. MARGIN abrupt or indistinct. HyPHAL STRANDS present, $70-150 \mu \mathrm{m}$ wide, situated near the basidiomata or radiating in flabelliform pattern from the margins. HYPHAL SYSTEM monomitic, hyphae clamped. Subicular hyphae moderately branched, $1.3-1.8 \mu \mathrm{m}$ wide, hyaline, thin-walled, in strands straight, $1-1.5 \mu \mathrm{m}$ wide. Subhymenium rich of fine crystalline material and also with groups of coarse crystals (separate crystals 2.5-11 $\mu \mathrm{m}$ across). Subbasidial hyphae moderately branched, 1.6-2(-3.5) $\mu \mathrm{m}$ wide, hyaline, thin-walled, moderately encrusted or smooth. Cystidia none. BASIDIA basally clamped, short clavate to subcylindrical, some with a median 


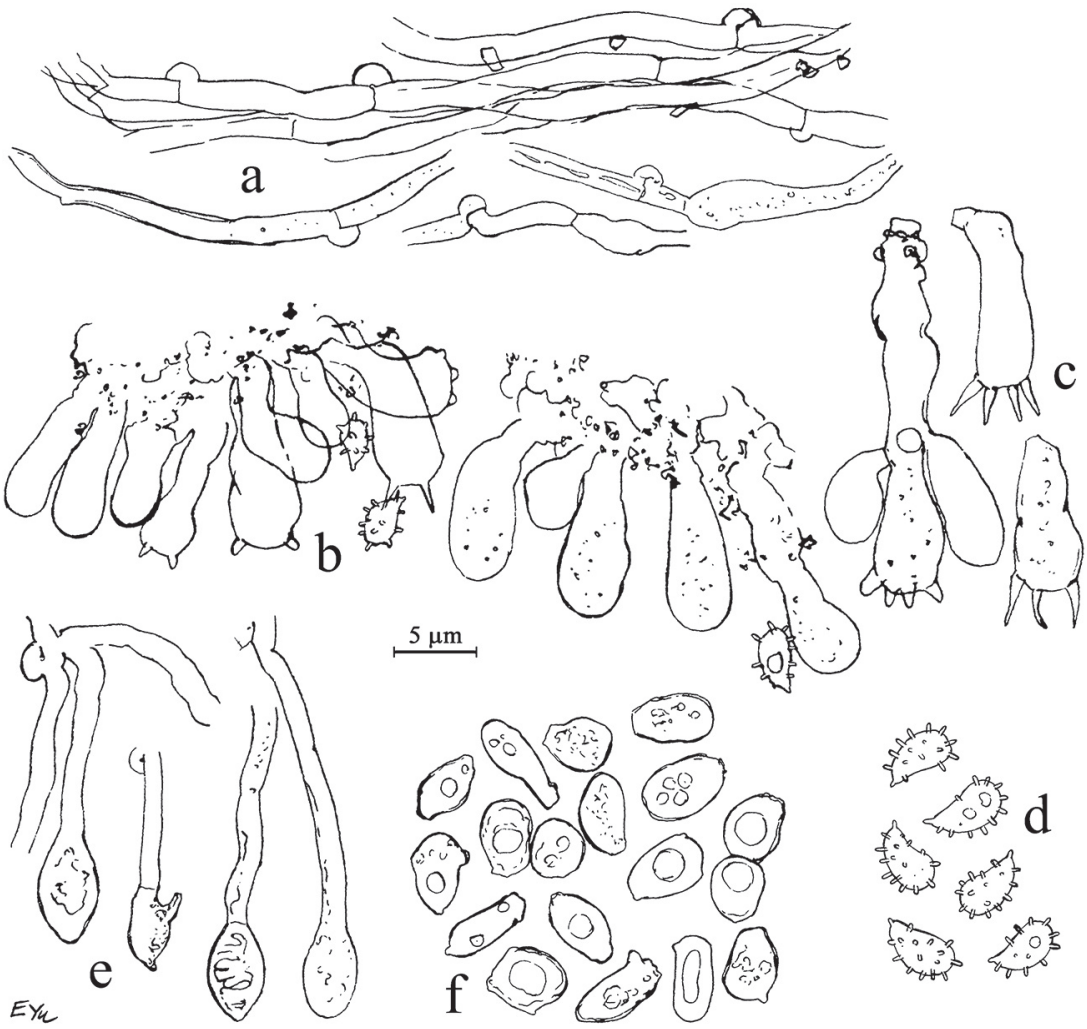

FIG. 6. Trechispora caucasica (MSK 6891): a, subicular hyphae; b, fragments of hymenium; c, basidia and basidioles; $\mathbf{d}$, basidiospores; e, conidiophores with developing conidia; $\mathbf{f}$, conidia.

constriction, thin-walled, hyaline, 9-11.5(-18) $\times 4-4.5(-5) \mu \mathrm{m}$, with $2-4$ sterigmata, $2.5-3.2 \times 0.5 \mu \mathrm{m}$. BAsIDIOSPORES ovoid, somewhat bent, adaxially concave, $3.3-4(-5.5) \times 2.5-2.7 \mu \mathrm{m}$, relatively evenly covered with spines up to $0.8 \mu \mathrm{m}$ long, thin-walled, hyaline, with middle-sized apiculus, Mz's-negative, acyanophylous. Conidia (blastoconidia) numerous, originating terminally, sometimes intercalarly, on delicate hyphae, 1-2 $\mu \mathrm{m}$ wide, ellipsoid, ovoid, angular-subglobose or irregular-shaped, 4.2-6.2 $\times 2.2-4 \mu \mathrm{m}$, smooth, or with one, or a few protuberances, with thickened walls, subhyaline, with one large drop or several smaller inclusions.

SPeCimen EXAMINED-BELARUS. Homel' voblast': Lel'chytsy district, Prypyatski National Park, in the vicinity of Simanichy village (site 3), on corticated fallen branch of Pinus sylvestris in Pinus forest of Pleurozium type, coll. 9.XI.2007 (MSK 6891; H.K.).

The presence of hyphal cords, lack of skeletal hyphae, often irregular shape of conidia, and especially morphology of basidiospores, which are ventrally 
somewhat concave and bearing comparatively long aculei, are characteristic for T. caucasica (Parmasto 1965, Larsson 1992). A very similar species is T. tenuicula (Litsch.) K.H. Larss., which, however, is dimitic, grows mostly on ferns (whereas T. caucasica grows on wooden substrata), and spores are ellipsoid to nearly lacrymiform, densely aculeate, with a small spine-free area on the ventral side (e.g., Larsson 1992, Kotiranta \& Saarenoksa 2000).

Trechispora caucasica is new for Belarus and known from a single locality. The species was described for the first time from Azerbaijan (Parmasto 1965, as 'Cristella caucasica Parmasto'), but today it is known from Britain (Kirk \& Cooper 2009 - 2 records), Norway (Ryvarden et al. 2003 - from 3 localities), Finland (Kotiranta et al. 2009 - 2 localities), Lithuania (R. Iršėnaitė 2010), Sweden, Denmark, France, Austria, Italy, USA (Larsson 1992), Azores (Telleria et al. 2009b). It is a rare or probably under-reported taxon, as earlier it was not distinguished from T. farinacea (Pers.) Liberta s. 1. (Liberta 1973, Hjortstam 1987, Domański 1992). However, Liberta (1973) did not describe blastoconidia or aleuriospores, typical of T. caucasica, in T. farinacea s.l. The distinction of T. caucasica from $T$. farinacea was made clear after the treatments by Larsson (1992; 1996).

Trechispora minuta K.H. Larss.

FIG. 7

BASIDIOMATA totally effused, closely adnate, very thin (about 15-20 $\mu \mathrm{m}$ thick), discontinuous, farinaceous or pruinose, 3-10 $\mathrm{mm}$ in extent, white. MARGIN diffuse, sometimes with very slender, closely adpressed, fan-shaped hyphal strands at the periphery. Hyphal system dimitic. Generative hyphae clamped, moderately branched, hyaline, thin-walled, smooth to slightly encrusted, (0.9-)1.3-2.3 $\mu \mathrm{m}$ wide, subbasidial ones 1.6-1.8(-4.2) $\mu \mathrm{m}$ wide. Hyphae in cords with blunt, cystidia-like hyphal ends up to $3.7-4.3 \mu$ m wide. Skeletals not present in all parts of basidiomata, but in some areas abundant, very sparingly branched, rather straight to wavy, hyaline, $0.5-1.1(-1.8) \mu \mathrm{m}$ wide, with lumen about $0.3 \mu \mathrm{m}$ wide or seemingly without lumen, gradually turning into narrow generative hyphae with clamps. Skeletals often covered with numerous, coarse (mostly 3-10 $\mu \mathrm{m}$ across) crystals. Hy PHIDIA occasional, sinuous, $18-32 \mu \mathrm{m}$ long, often swollen at base to about $4 \mu \mathrm{m}$. BAsidia basally clamped (clamps often obscured by fine crystalline material), shortly clavate to oblong and slightly pedunculate, straight or curved, 7.5-9.2 $\times(3.3-) 3.5-4 \mu \mathrm{m}$, with 4 subulate sterigmata $3.3(-4) \mu \mathrm{m} \times 0.5 \mu \mathrm{m}$. BAsidiospores ellipsoid or ovoid, with flat or convex ventral side, minutely echinulate to short aculeate, $3.3-3.8(-4.5) \times 1.7-2.1 \mu \mathrm{m}$ excluding the aculei, hyaline, thin- or rather thinwalled, Mz's-negative, acyanophilous, with minute or indistinct apiculus.

SPECIMEN EXAMINED-BELARUS. Homel' voblast': Mazyr district, NW outskirts of town Mazyr (site 2), in ravine bottom, on angiosperm twig in litter in Alnus glutinosa forest of Rubus idaeus-Oxalis type, coll. 26.X.2006 (MSK 7307; H.K.). 

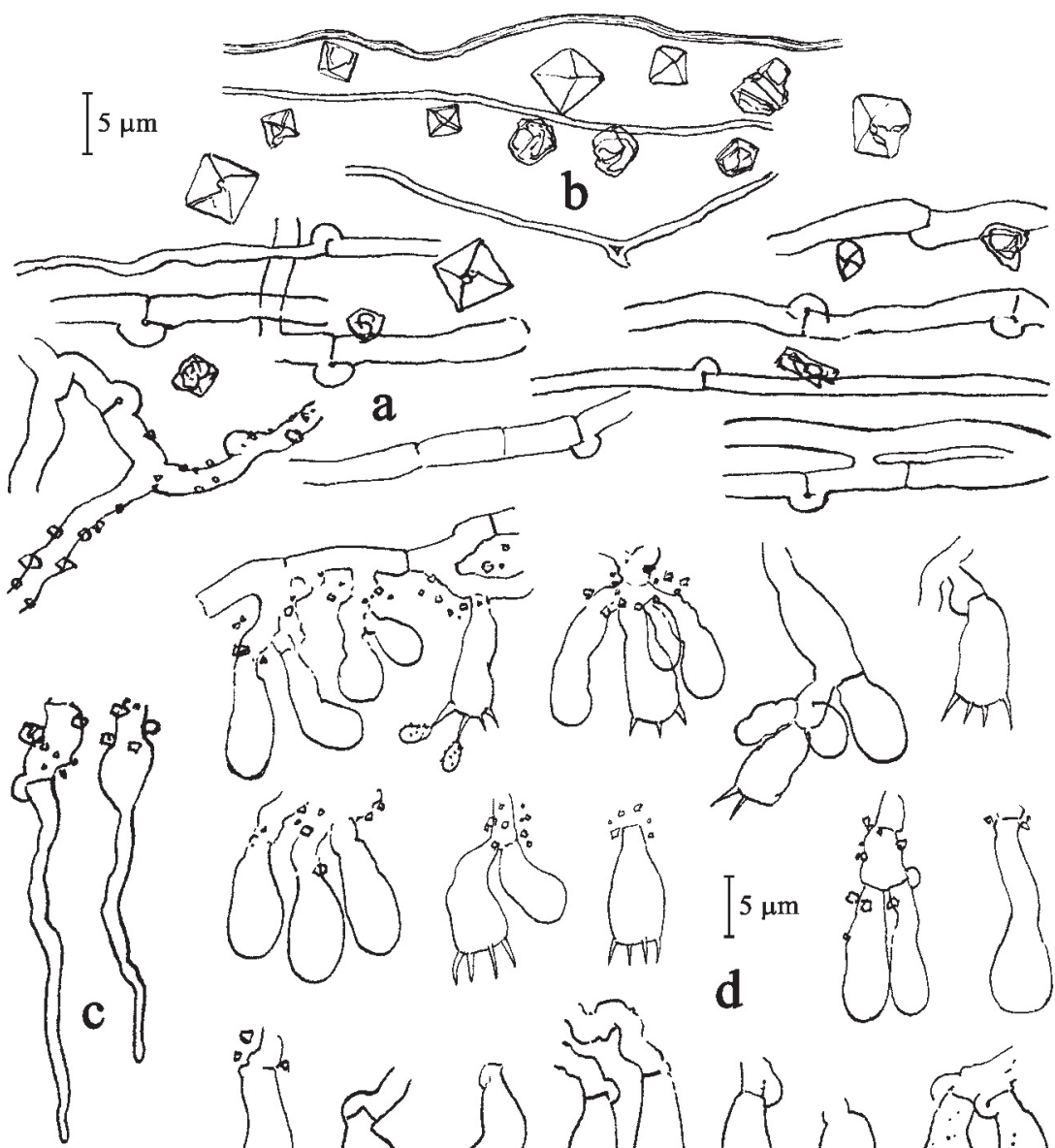

EYe
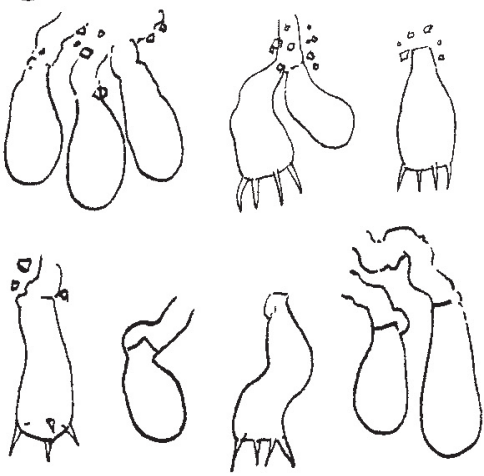

d
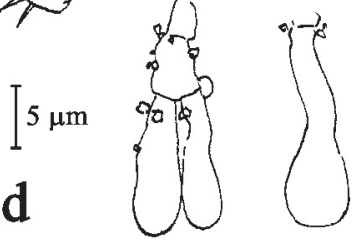

$\therefore\left\{\begin{array}{l}5 x \\ \therefore \\ 0 \\ 0\end{array}\right\}$
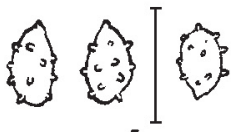

$5 \mu \mathrm{m}$
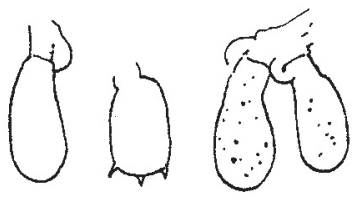

FIG. 7. Trechispora minuta (MSK 7307): a, generative hyphae; b, skeletal hyphae and crystals; c, hyphidia; $\mathbf{d}$, basidioles and basidia; e, basidiospores.

The main distinctive characters for T. minuta are the presence of skeletal hyphae, usually pruinose to farinaceous basidiomata, very short basidia $(\leq 10 \times 5 \mu \mathrm{m})$, and a subhymenium of intricately branched hyphae in fully mature specimens 
(Larsson 1992). Trechispora tenuicula differs in having longer basidia (10-13 $\mu \mathrm{m})$ and the presence of blastoconidia. In contrast to the original description of T. minuta, our sample has an undeveloped subhymenium and narrower basidiospores with rather evenly distributed aculei. According to Larsson (1992, Fig. 28) spores are 2.4-2.7 $\mu \mathrm{m}$ wide without aculei and have almost a smooth area on the ventral side near the apiculus.

The species is new for Belarus and known from a single locality. It is widely distributed and presumably common, but is evidently neglected or often misidentified. The species is known from Norway (10 localities), Sweden (7 localities), Finland, France, Austria, Poland (at the eastern border close to Belarus), Canada, USA (Larsson 1992), and Azores (Telleria et al. 2009b).

\section{Acknowledgments}

The authors are grateful to Prof. Nils Hallenberg (Department of Plant and Environmental Sciences, University of Göteborg, Sweden) and to Dr Wolfgang Dämon (St. Georgen bei Salzburg, Austria) for presubmission review of the manuscript. We are thankful to Dr Karl-Henrik Larsson (Natural History Museum, University of Oslo, Norway) for the identification of Crustodontia chrysocreas and giving some data on its distribution, and to Dr Bernhard de Vries (Hoogeveen, The Netherlands) for the discussion on Hyphoderma cryptocallimon taxonomy.

\section{Literature cited}

Berkeley MJ. 1873. Notices of North American fungi. Grevillea 1(12): 177-180.

Bernicchia A. 2000. Wood-inhabiting aphyllophoraceous fungi on Juniperus spp. in Italy. Mycotaxon 75: 241-256.

Bernicchia A, Gorjón SP. 2010. Corticiaceae s.l. Fungi Europaei n¹2. Ed. Candusso, Italia. 1008 pp.

Bernicchia A, Savino E, Gorjón SP. 2007a. Aphyllophoraceous wood-inhabiting fungi on Pinus spp. in Italy. <http://www.mycotaxon.com/resources/checklists/bernicchia-v101-checklist1. pdf $>$. (Summary of web publication: Mycotaxon 101: 5-8.)

Bernicchia A, Venturella G, Saitta A, Gorjón SP. 2007b. Aphyllophoraceous wood-inhabiting fungi on Fagus sylvatica in Italy. <http://www.mycotaxon.com/resources/checklists/ bernicchiav101-checklist2.pdf > . (Summary of web publication: Mycotaxon 101: 229-232.)

Bernicchia A, Benni A, Venturella G, Gargano ML, Saitta A, Gorjón SP. 2008. Aphyllophoraceous wood-inhabiting fungi on Quercus spp. in Italy. <http://www. mycotaxon.com/resources/ checklists/bernicchia_v104-checklist.pdf > (Summary of web publication: Mycotaxon 104: 425-428.)

Bourdot H, Galzin A. 1928. Hyménomycètes de France. Hetérobasidiés - Homobasidiés Gymnocarpes [Contribution a la flore mycologique de la France 1]. Paris: Lechevalier. 764 pp.

Dai YC. 2010. A revised checklist of corticioid and hydnoid fungi in China for 2010. Mycoscience. Published online 31 Aug 2010. doi:10.1007/s10267-010-0068-1

Dai YC, Wei YL, Zhang XQ. 2004. An annotated checklist of non-poroid Aphyllophorales in China. Ann. Bot. Fennici 41: 233-247.

Domański S. 1991. Mała flora grzybów. T. 1. Basidiomycetes (Podstawczaki). Aphyllophorales (Bezblaszkowce), Stephanosporales (Stefanosporowce). Część 6. Corticiaceae: Kavinia 
- Rogersella. Stephanosporaceae: Lindtneria. Państwowe wydawnictwo naukowe: Warszawa, Kraków. 273 pp.

Domański S. 1992. Mała flora grzybów. T. 1. Basidiomycetes (Podstawczaki). Aphyllophorales (Bezblaszkowce). Część 7. Corticiaceae: Sarcodontia - Ypsilonidium, Christiansenia \& Syzygospora. Instytut botaniki im. W. Szafera: Kraków. 258 pp.

Eriksson J, Ryvarden L. 1975. The Corticiaceae of North Europe. Vol. 3: Coronicium - Hyphoderma. Fungiflora: Oslo. Pp. 287-546.

Ghobad-Nejhad M, Hallenberg N, Parmasto E, Kotiranta H. 2009. A first annotated checklist of corticioid and polypore basidiomycetes of the Caucasus region. Mycologia Balcanica 6: 123-168.

Gilbertson RL, Adaskaveg JE. 1993. Studies on wood-rotting basidiomycetes of Hawaii. Mycotaxon 49: 369-397.

Hauerslev K, Roberts P. 1997. Ceratobasidiaceae Jülich. 112-115, in: Hansen L, Knudsen H. (eds), Nordic macromycetes. Vol. 3: Heterobasidioid, aphyllophoroid and gastromycetoid Basidiomycetes. Nordsvamp: Copenhagen.

Hjortstam K. 1987. A check-list to genera and species of corticioid fungi (Hymenomycetes). Windahlia 17: 55-85.

Hjortstam K, Ramos Bononi VL. (1987). A contribution to the knowledge of Corticiaceae s.l. (Aphyllophorales) in Brazil. Mycotaxon 28(1): 1-15.

Hjortstam K, Ryvarden L, Watling R. 1993. Preliminary checklist of non-agaricoid macromycetes in the Korup National Park, Cameroon and surrounding area. Edinb. J. Bot. 59(1): 105-119. doi:10.1017/S0960428600000743

Hjortstam K, Roberts PJ, Spooner BM. 1998. Corticioid fungi from Brunei Darussalam. Kew Bulletin 53(4): 805-827. doi:10.2307/4118870

Hjortstam K, Roberts PJ, Spooner BM. 2009. Corticioid fungi from the Kimberley Region, Western Australia. Kew Bulletin 64(2): 353-368. doi: 10.1007/s12225-009-9104-8.

Iršènaitė R. 2010. Aa annotated checklist of corticioid fungi of Lithuania. Bothanica Lithuanica 16(2-3): 83-95.

Kirk P, Cooper J. 2009. The checklist of fungi of the British Isles - name search. British Mycological Society, FRDBI [website]. <http://www.fieldmycology.net/GBCHKLST/ gbchklst.asp >.

Klitsunova NK, Martsynkevich HI, Pirozhnik II, Shchasnaya II, Yakushka VP. 2002. Map 17. Physiographic division (in European decimal division system). In: Myasnikovich MU, Shymau UM et al. (eds), National atlas of Belarus: 152. Belkartahrafiya; KPZRHiK: Minsk. [in Belarusian]

Kotiranta H, Saarenoksa R. 2000. Corticioid fungi (Aphyllophorales, Basidiomycetes) in Finland. Acta Bot. Fennica 168: 1-55.

Kotiranta H, Saarenoksa R. 2005. Ceratobasidium and Oliveonia (Basidiomycota, Aphyllophorales) in Finland. Ann. Bot. Fennici 42: 237-245.

Kotiranta H, Saarenoksa R, Kytövuori I. 2009. Aphyllophoroid fungi of Finland: A check-list with ecology, distribution, and threat categories [Norrlinia 19]. Botanical Museum, Finnish Museum of Natural History: Helsinki. 223 pp.

Kubayashi T, Maekawa N. 2001. Identification and pathogenicity of the fungus isolated from butt rot of Japanese cypress, Chamaecyparis obtusa. J. Gen. Plant. Pathol. 67: 262-267. doi:10.1007/ $\underline{\text { PL00013027 }}$

Küffer N, Lovas PS, Senn-Irlet B. 2004. Diversity of wood-inhabiting fungi in natural beech forests in Transcarpathia (Ukraine): a preliminary survey. Mycologia Balcanica 1: 129-134.

Larsson KH. 1992. The genus Trechispora (Corticiaceae, Basidiomycetes). Dissertation. Göteborg. 
Larsson KH. 1996. Taxonomy of Trechispora farinacea and proposed synonyms II. Species with a smooth hymenophore. Nordic J. Bot. 16(1): 73-82. doi:10.1111/j.1756-1051.1996.tb00217.x

Liberta AE. 1973. The genus Trechispora (Basidiomycetes, Corticiaceae). Can. J. Bot. 51(10): 1871-1892. doi:10.1139/b73-240

Lin SH, Chen ZC. 1990. The Corticiaceae and the resupinate Hydnaceae of Taiwan. Taiwania 35(2): 69-111.

Lombard FF, Burdsall HH, Gilbertson RL. 1975. Taxonomy of Corticium chrysocreas and Phlebia livida. Mycologia 67(3): 495-510. doi:10.2307/3758388

Maekawa N. 1993. Taxonomic study of Japanese Corticiaceae (Aphyllophorales) I. Rept. Tottori Mycol. Inst. 31: 1-149.

Maekawa N. 1994. Taxonomic study of Japanese Corticiaceae (Aphyllophorales) II. Rept. Tottori Mycol. Inst. 32: 1-123.

Malysheva VF, Malysheva EF. 2008. The higher basidiomycetes in forest and grassland communities of Zhiguli. KMK Scientific Press: Moscow, St. Petersburg. 243 pp.

Minter DW (ed.) 2010. Cybertruffle's robigalia. Observations of fungi and their associated organisms [website]. Retrieved at <http://www.cybertruffle.org.uk/robigalia/eng/ index.htm $>$ 11 Nov 2010.

Minter DW, Mena Portales J, Rodríguez-Hernández M, Iglesias Brito H, Camino Vilaró M, Mercado Sierra Á. (2002). Electronic distribution maps of Caribbean fungi [website, version 1.00]. <http://www.biodiversity.ac.psiweb.com/carimaps $>$.

Nakasone KK, Gilbertson RL. 1982. Three brown-rot fungi in the Corticiaceae. Mycologia 74(4): 599-606.

Nikolajeva TL. 1961. Familia Hydnaceae. Flora plantarum cryptogamarum URSS. 6: Fungi (2). Typ. et imp. Acad. Sc. URSS: Moscow, Leningrad. 433 pp. [in Russian]

Parmasto E. 1965. Corticiaceae URSS. I. Descriptiones taxorum novarum. Combinationes novae. Eesti NSV Tead. Acad. Toim., Biol. 14(2): 220-233.

Pennycook SR, Galloway DJ. 2004. Checklist of New Zealand "fungi”. Fungi of New Zealand 1: 401-488. Fungal Diversity Press: Hong Kong.

Roberts P. 1999. Rhizoctonia-forming fungi: A taxonomic guide. The Herbarium, Royal Botanic Gardens: Kew. 239 pp.

Roberts P. 2000. Corticioid fungi from Korup National Park, Cameroon. Kew Bulletin 55(4): 803-842. doi: $10.2307 / 4113628$

Ryvarden L, Stokland J, Larsson KH. 2003. A critical checklist of corticioid and poroid fungi of Norway. Synopsis Fungorum 17: 1-109.

Telleria MT, Melo I, Dueñas M, Salcedo I, Cardoso J, Rodríguez-Armas JL, Beltrán-Tejera E. 2008. Corticioid fungi (Basidiomycota) from Madeira Island. <http://www.mycotaxon. com/ resources/checklists/telleria-v106-checklist.pdf $>$. (Summary of web publication: Mycotaxon 106: 419-422.)

Telleria MT, Melo I, Dueñas M, Rodríguez-Armas JL, Beltrán-Tejera E, Cardoso J, Salcedo I. 2009a. Diversity and richness of corticioid fungi (Basidiomycota) on Azores Islands: a preliminary survey. Nova Hedwigia 88(3-4): 285-308. doi:10.1127/0029-5035/2009/0088-0285

Telleria MT, Melo I, Dueñas M, Salcedo I, Cardoso J, Rodríguez-Armas JL, Beltrán-Tejera E. $2009 \mathrm{~b}$. Corticioid fungi (Basidiomycota) from the Azores Islands: Flores and São Miguel. <http:// www.mycotaxon.com/resources/checklists/telleria-v109-checklist.pdf $>$. (Summary of web publication: Mycotaxon 109: 141-144.)

Vries BWL de. 1987. Some new corticioid taxa. Mycotaxon 28(1): 77-90.

Wu SH. 1990. The Corticiaceae (Basidiomycetes) subfamilies Phlebioideae, Phanerochaetoideae and Hyphodermoideae in Taiwan. Acta Bot. Fenn. 142: 1-123. 
Yurchenko E. 2008. Corticioid fungi (Basidiomycota) on living wooden plants in Belarus: species inventory and host colonization strategies. Botanica Lithuanica 14(3): 177-189.

Yurchenko EO, Kotiranta H. 2006. Rare corticioid fungi (Basidiomycetes, Aphyllophorales) from central Belarus. Mycena 6: 67-88.

Yurchenko EO, Kotiranta H. 2007. Rare corticioid fungi (Basidiomycetes, Aphyllophorales) from northern Belarus. Mycena 7: 20-47.

Zerova MYa, Radziyevs'kyi HH, Shevchenko SV. 1972. Fungi of Ukraine identification book. T. 5. Basidiomycetes. Book 1. Exobasidiales, Aphyllophorales, Cantharellales. Naukova dumka: Kyiv. 240 pp. [in Ukrainian] 